\title{
Immunohistological Characterization of Intraepithelial and Lamina Propria Lymphocytes in Control Ileum and Colon and in Inflammatory Bowel Disease
}

\author{
ICHIRO HIRATA, MD, GABRIEL BERREBI, MD, LINDA L. AUSTIN, BA, \\ DAVID F. KEREN, MD, and WILLIAM O. DOBBINS III, MD
}

\begin{abstract}
Using monoclonal antibodies to $T$ and $B$ lymphocytes, to natural killer cells, and to HLA-DR antigen, we characterized the lymphocyte population within the epithelial and lamina propria regions in control intestine and colon, and in grossly involved and in grossly uninvolved intestine and colon of patients with active inflammatory bowel disease. There were significantly more intraepithelial $T$ cells in control ileum than in control colon. In comparison to control, there was a heterogeneity of alterations in intraepithelial and lamina propria $T$ lymphocyte subsets $\left(\mathrm{T}_{1} 1^{+}, \mathrm{T}^{+}, \mathrm{T4}^{+}\right)$in inflammatory bowel disease. $B$ lymphocytes were not detected within the lamina propria, except when found in and adjacent to lymphoid aggregates. Leu $7^{+}$cells were uncommon in the lamina propria of control ileum and colon and in diseased tissues. The majority of intraepithelial lymphocytes did not express HLA-DR. Epithelial cells of control colon did not express HLA-DR while epithelial cells of control ileal tissues and of diseased colonic and ileal specimens expressed HLA-DR antigen. Only small numbers of lamina propria $T$ cells expressed $H L A-D R$ in both control and disease tissues. There was intense expression of HLA-DR by monocytes and modest expression of HLA-DR by capillary and lymphatic endothelial cells. The induction of HLA-DR expression by diseased colonic epithelium and the observation that lymphatic endothelium expresses HLA-DR are new observations, and we established that Leu $7^{+}$cells are present in very small numbers in both normal and diseased intestine and colon.
\end{abstract}

The mucosa of the human intestine is rich in mononuclear cells, the predominant cell types being lymphocytes, plasma cells, and macrophages. The

Manuscript received February 11, 1985; revised manuscript received May 17, 1985; accepted August 15, 1985.

From the Departments of Internal Medicine and Pathology, University of Michigan Medical School and Veterans Administration Medical Center, Ann Arbor, Michigan.

Supported by funding from the National Foundation for lleitis and Colitis and by Merit Review funds from the Veterans Administration.

Address for reprint requests: Dr. William O. Dobbins III, Veterans Adrninistration Medical Center, 2215 Fuller Road, Ann Arbor, Michigan 48105. cells of the mucosa are found in two separate regions, one consisting of lymphocytes (LPL) and mononuclear cells (MNC) located within the lamina propria and the other consisting largely of lymphocytes located within the epithelial cell layer, intraepithelial lymphocytes (IEL) (1-8). Definition of the distribution of lymphocytes in normal gut and in the intestine and colon of inflammatory bowel disease (IBD) may provide new insights concerning the immunopathology of IBD. Cerf-Bensussan et al have provided data in this regard in three control intestinal specimens (3), while Selby et al have 
reported data in control colon and in the colon of ulcerative colitis (UC) and of Crohn's disease (CD) (4). Using monoclonal antibodies to $\mathrm{T}$ lymphocytes (T11, T8, T4), B lymphocytes (B1), natural killer cells (Leu 7), and human leukocyte antigen, DR (HLA-DR) antigen (I2), we have further characterized the distribution of lymphocyte subsets in the intestinal and colonic mucosa of controls and of patients with ileal and colonic Crohn's disease and of patients with ulcerative colitis. Our data confirms and considerably extends the earlier observations $(3,4)$.

\section{MATERIALS AND METHODS}

Source of Tissue. Specimens of intestinal tissue were obtained from surgical procedures performed for diagnostic and therapeutic purposes at the University of Michigan affiliated hospitals. The specimens used for control purposes were obtained from grossly and histologically normal margins of 10 colonic (all colon cancer) and seven ileal specimens (five colon cancer, one chronic pancreatitis, one benign ileal stricture) obtained from patients without inflammatory bowel disease of the intestine. The IBD specimens were obtained from 11 patients with ulcerative colitis (nine surgical resections, two endoscopic procedures) and 11 surgical resections of patients with Crohn's disease, all specimens showing characteristic features of disease grossly and microscopically. Whenever possible, grossly normal-appearing margins from the uninvolved area in the IBD specimens were obtained for comparison to the grossly affected areas of disease (four UC and eleven CD). None of the grossly normal margins of IBD specimens were used to define control values. All specimens showed histologic changes of active IBD including acute and chronic inflammation, crypt epithelial damage, and often mucus depletion. The studies described were approved in advance by the Human Studies Committee at the respective hospitals.

The tissue specimens were obtained immediately after resection and placed in OCT compound, Tissue Tek II (Lab Tek Products, Division of Miles Laboratory, Napeville, Illinois) and quick frozen in 2-methylbutane (isopentane) (J. T. Baker Chemical Co., Phillipsburg, New Jersey) cooled in liquid nitrogen (9). Specimens were stored at $-70^{\circ} \mathrm{C}$ until prepared for staining.

Patient Treatments. Of the 11 patients with ulcerative colitis, two were receiving corticosteroids alone, three were receiving sulfasalazine (Azulfidine, Pharmacia, Inc.) alone, and four were receiving both corticosteroids and sulfasalazine at the time the tissue specimens were obtained. Of the 11 patients with Crohn's disease, four were receiving corticosteroids alone, four were on sulfasalazine, and three were being treated with both agents. Clinical activity was determined by patient history, ie, presence or absence of abdominal pain, blood per rectum, number of stools per day, fever, and arthralgias. Chemical parameters evaluated included CBC and differential, albumin, and potassium levels. All patients except one were clinically active when the specimen was collected.
Monoclonal Antibodies. Monoclonal antibodies were used to stain T lymphocytes and their subsets, B cells, natural killer cells, and cells expressing HLA-DR-like surface antigen. The monoclonal antibodies to B cells, HLA-DR-like antigen, and T lymphocytes and their subsets were of the Coulter Clone ${ }^{\mathrm{TM}}$ group, (Coulter Immunology, a division of Coulter Corporation, Hialeah, Florida). The monoclonal antibody to natural killer cells was obtained from Becton Dickinson Monoclonal Antibody Center (Sunnyvale, California). The specificity of the individual monoclonal antibodies is as follows: anti-T11 identifies the antigen found on greater than $95 \%$ of thymocytes and $100 \%$ of $\mathrm{E}$ rosetting-positive lymphocytes, and inhibits sheep erythrocyte rosette formation. Anti-T8 adheres to the lymphocyte surface antigen which identifies suppressor lymphocytes. Anti-T4 identifies $\mathrm{T}$ lymphocytes which provide a helper role. Anti-Leu 7 reacts with lymphocytes exhibiting natural killer cell activity. Anti-I2 reacts with surface Ia-like (HLA-DR) antigen found on normal B cells, monocytes, and activated $\mathrm{T}$ lymphocytes. $\mathrm{B} 1$ antibody reacts with normal $\mathrm{B}$ cells. The antigen detected by B1 antibody is lost prior to the cells' differentiation into a plasma cell. The dilutions found to be optimal were as follows: anti-T11 $=1: 1280$, anti-T8 $=1: 160$, anti-T4 $=1: 160$, anti-Leu $7=1: 320$, anti-Bi $=1: 40$, anti-I2 $=1: 2560$ and 1:5120. The above concentrations were obtained by diluting the stock solution in $2 \%$ fetal calf serum (FCS) in phosphate-buffered saline (PBS) with $0.002 \%$ merthiolate used as preservative. These dilutions optimized localization of cells and decreased background diffusion of antibody. Monoclonal antibody stock solutions were stored at $-20^{\circ} \mathrm{C}$ and diluted aliquots were kept for a maximum of 30 days at $4^{\circ} \mathrm{C}$. The working solutions were stored at $4^{\circ} \mathrm{C}$ for no longer than $24 \mathrm{hr}$ and then discarded. All monoclonal antibodies were shown to stain peripheral blood mononuclear cells of normal individuals in appropriate proportions. Controls consisted of staining of sections in the absence of primary antibody and staining of sections with aminoethylcarbazole alone (see below). Also, selected tissues were stained with mouse IgG and IgM in order to check for nonspecific binding of mouse antibody. To look for endogenous avidin-binding activity (EABA), a subset of tissue sections were incubated with avidin, $1 \mathrm{mg} / \mathrm{ml}$ in PBS for $20 \mathrm{~min}$, and biotin, $0.1 \mathrm{mg} / \mathrm{ml}$ in PBS for $20 \mathrm{~min}$, prior to staining (10). No EABA was detected in the four control and four disease specimens stained.

Immunoperoxidase Procedure. Frozen tissue sections were cut on a cryostat microtome (Ames Cryostat II, Miles Lab.) and stained according to Warnke and Levy (9). Cryostat sections $4 \mu \mathrm{m}$ thick were mounted on microslides previously coated with $0.5 \%$ albumin in $0.1 \%$ ammonia in water (11). The tissue sections were fixed in acetone at room temperature for less than $5 \mathrm{sec}$ and stored at $-20^{\circ} \mathrm{C}$ until used. Sections selected for staining were fixed in cold acetone for an additional $10 \mathrm{~min}$, then incubated with the appropriate dilution of the working antibody for $15 \mathrm{~min}$ followed by normal horse or goat serum (5\% serum in 2\% FCS in PBS) for $20 \mathrm{~min}$ (9). This was followed by incubation with a 1:100 dilution (15 $\mu \mathrm{g} / \mathrm{ml}$ ) of biotinylated horse antimouse IgG (Vector Labs., Burlingame, California) or biotinylated goat anti- 
mouse $\operatorname{IgM}$ (Vector Labs) in $2 \% \mathrm{FCS} / \mathrm{PBS}$ depending on the immunoglobulin class of the primary antibody $(9,12)$. The section was then incubated with avidin-horseradish peroxidase (HRP) (Vector Labs) at a final concentration of $25 \mu \mathrm{g} / \mathrm{ml}$ diluted in $2 \%$ FCS in PBS at pH 7.2 for $15 \mathrm{~min}$ $(13,14)$. Each incubation was followed by two 3-min PBS $(\mathrm{pH}$ 7.4) washes. After the avidin-HRP incubation the sections were incubated with a solution of 3-amino-9ethylcarbazole (AEC) (Sigma Chemical Company, St. Louis, Missouri) in $N, N$-dimethylformamide and $0.05 \mathrm{M}$ acetate buffer $\mathrm{pH}, 5.0$ with $0.5-3 \%$ hydrogen peroxide for 3-5 min, washed in PBS for 3 min and postfixed in 4\% formaldehyde for $5 \mathrm{~min}$ (3). All sections were counterstained with Mayer's hematoxylin for $5 \mathrm{~min}$ and mounted in Gelvatol (Monsanto, Springfield, Massachusetts) (3).

Inactivation of Endogenous Peroxidase. There are a number of cells in the lamina propria, especially of diseased tissues that contain endogenous peroxidase (PMN and eosinophilic leukocytes, mast cells, and macrophages). Considerable effort was made to develop methods for inhibiting endogenous peroxidase (EP), but most of the approaches that work for standard antibody localization were found to inactivate the antigenic sites recognized by the monoclonal antibodies utilized. $\mathrm{H}_{2} \mathrm{O}_{2}$ in methanol, periodic acid-sodium borohydride (15), and $0.1 \%$ phenylhydrazine (16) either failed to adequately inhibit EP, or abolished all monoclonal antibody staining. Incubation of the sections in varying concentrations of sodium azide at various temperatures (17) resulted in moderate success in inhibiting EP without affecting antigenic sites to monoclonal antibodies. Thus, we stained all tissues with the specific monoclonal antibody in the presence and absence of sodium azide (Fisher Scientific Co., Fairlawn, New Jersey) $0.25 \mathrm{M}$ in $0.25 \mathrm{M}$ phosphate buffer, $\mathrm{pH} 5.0$, for $30 \mathrm{~min}$ at $37^{\circ} \mathrm{C}$. The treatment with azide was done after the incubation with biotinylated secondary antibody. The azide incubation was followed by a 20-min wash in PBS. The sections were then treated with avidin-horseradish peroxidase and AEC.

All counts were made of slides incubated in both the presence and absence of sodium azide. We may have overestimated the number of positively stained cells in untreated slides, and we may have underestimated the number of positively stained cells in the azide-treated slides. The data for both groups were analyzed separately and not found to be statistically different. The results were thus combined.

Double Staining with Peroxidase and Fluorescein. Tissue sections were prepared as previously described and stained with anti-human HLA-DR antibody (biotin conjugated) (Becton-Dickinson, Mountain View, California) for $15 \mathrm{~min}$, washed in PBS, and incubated with avidin-HRP (Vector Labs.) for $15 \mathrm{~min}$. After a PBS wash, the avidin-HRP was developed by a 4-min incubation with AEC as described. After a 10-min wash in PBS, the tissue was incubated with anti-T11 antigen-fluorescein isothiocyanate conjugate (Coulter Clone ${ }^{\mathrm{rM}}$, Coulter Leasing Corp., Hialeah, Florida) for $30 \mathrm{~min}(10,18)$. The section was then washed and mounted in Gelvatol (3). Control sections were stained consecutively with the same antibody in order to show that the first conjugated antibody blocked subsequent staining with the second conjugate of the same antibody. In order to exclude inhibition of binding by each of the antibodies, the slides were stained by exchanging the fluorescent and avidin preparations and then compared (10). Counting was performed on a Zeiss epifluorescent microscope at a magnification of $400 \times$, using water-immersion objectives.

Method of Quantitation. All tissue sections were first observed under $100 \times$ magnification to assess integrity of the tissue section. The section was then scanned at $400 \times$, and cells stained positively with the monoclonal antibody were counted. The specific reaction of the monoclonal antibody with the appropriate surface antigen was defined as a circumferential staining of a bright reddish brown color with minimal diffusion. The labeled IEL were counted per 100 epithelial cells by counting only areas where epithelial cells were normally sectioned (2). Counts were performed over the entire villous surface (3). A minimum of 500 epithelial cells were counted. When subsets of cells were exceedingly sparse (Leu $\left.7^{+}, \mathrm{B}^{+}\right)$, the number of cells per high-power field (HPF, $400 \times$ ) were counted. In the presence of trauma, the IEL were not counted. In order to count LPL, the sections were then scanned at $400 \times$ and all mononuclear cells (excluding swollen capillary endothelia) were counted within an area positively defined by a grid (1408A from AO Spencer), and cells stained with the monoclonal antibody were counted within the same grid area. The specific reaction of the monoclonal antibody with the appropriate surface antigen was defined as circumferential staining of a bright reddish brown color with minimal diffusion. This contrasted to endogenous peroxidase found in granulocytes and in macrophages which was nonspecific staining consisting of a dull brown color, was granular, and clearly cytoplasmic in location. Mononuclear cells with the characteristic elongated appearance of fibroblasts were not counted. At least 500 mononuclear cells were counted for each monoclonal antibody stained section. In order to determine which $\mathrm{T}_{11}{ }^{+}$cells were also activated, doublestained slides were first observed by light microscopy to document presence of $\mathrm{I} 2$ antigen, and then the identical cell was examined for expression of T11 surface antigen by epifluorescence.

Statistical Analysis. The Student's $t$ test was used for all calculations.

\section{RESULTS}

IEL in Control Specimens. Virtually all IEL were $\mathrm{T}_{1} 1^{+}$cells, and ileal tissues contained significantly greater numbers of $\mathrm{T}_{1} 1^{+}, \mathrm{T}^{+}$, and $\mathrm{T} 4^{+} \mathrm{IEL}$ (Figure 1A-D) than control colonic tissues (Table 1). The predominant IEL subtype was the $\mathrm{T} 8^{+}$lymphocyte, which accounted for $>80 \%$ of IEL. The $\mathrm{T} 4^{+} / \mathrm{T} 8^{+}$ ratios in colon and ileum were similar. IEL stained with anti-B1 antibody were rarely detected in colon (2/251 HPF) or in ileum (2/172 HPF). Two Leu 7 positively stained IEL were noted in $1 / 7$ ileal specimens $(287 \mathrm{HPF})$ and two Leu $7^{+}$cells were found in 

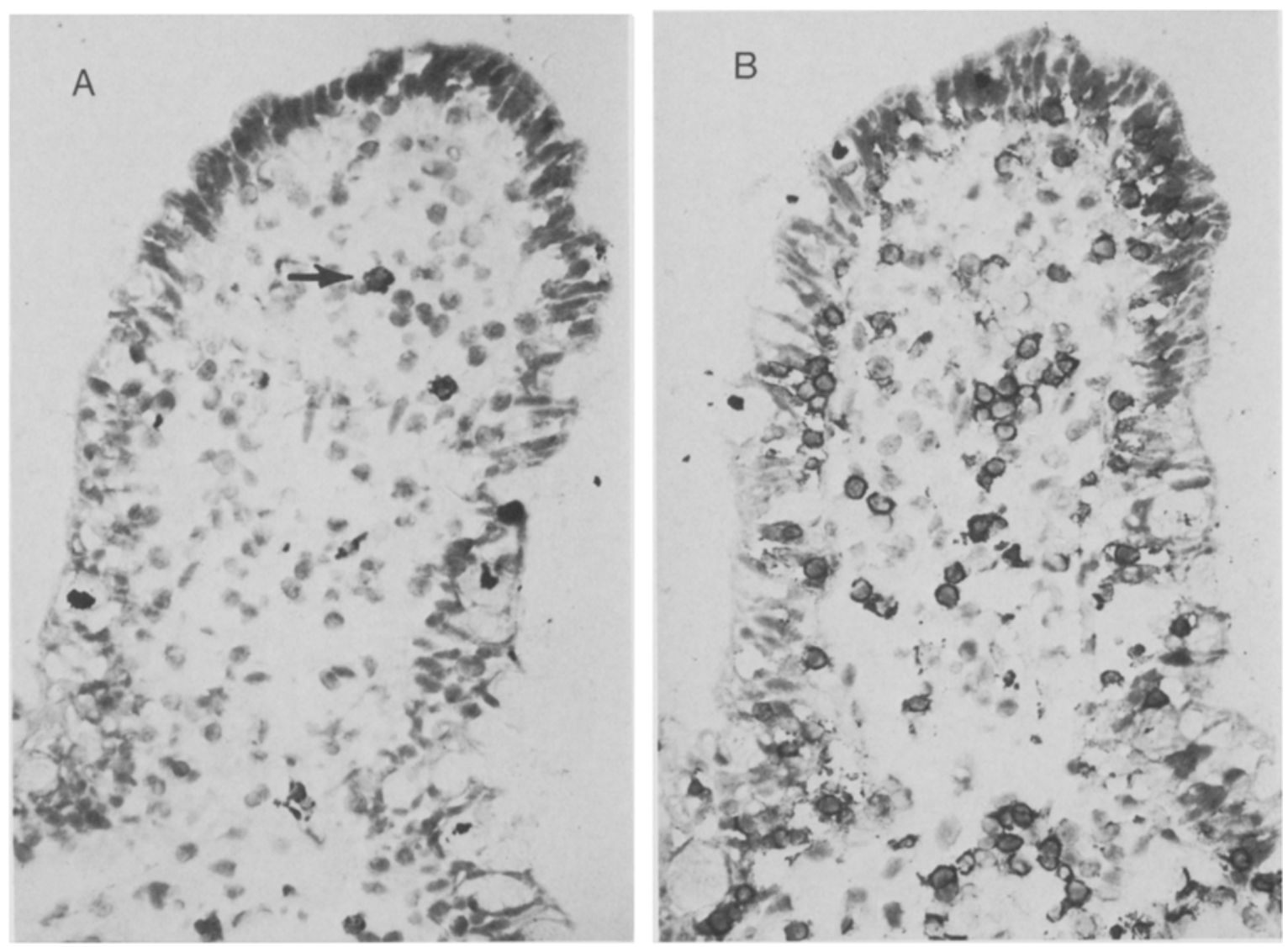

Fig 1. (A) Immunoperoxidase staining in the absence of monoclonal antibody (control). Note endogenous peroxidase reaction in granulocytes (arrow). All figures in 1A-D were obtained from serial sections of normal intestinal mucosa and are magnified approximately $250 \times$. (B) Staining with monoclonal antibody to T11 surface antigen showing typical peripheral staining of T cells in both lamina propria and in epithelium. (C) Staining with monoclonal antibody to T4 surface antigen (T helper). Few IEL (arrow) were stained with anti-T4 antibody. (D) Staining with monoclonal antibody to T8 surface antigen (T suppressor). Note numerous IEL staining with anti-T8 antibody.

2/10 colonic specimens (611 HPF). The epithelium of normal ileal specimens stained diffusely with anti-I2, the most intense localization being at the apex of epithelial cells. The epithelial cells of control colon specimens did not stain with this antibody (Figure 2A). IEL did not stain. Mouse IgG and IgM did occasionally bind nonspecifically to goblet cell mucus and to mucus in the lumen, but there was no nonspecific binding over other cellular components, including epithelial cells devoid of mucus. On occasion, the number of $\mathrm{T}^{+}$and $\mathrm{T}^{+}$cells slightly exceeded the number of $\mathrm{T}_{1} 1^{+}$cells. This probably relates to the occasional loss of $\mathrm{T} 11$ antigen expression by $\mathrm{T}^{+}$and $\mathrm{T} 8^{+}$cells (3).

LPL in Control Specimens. Control ileal specimens had a significantly greater number of $\mathrm{T} 11^{+}$ LPL than control colonic tissues $(P<0.05)$ (Table 1), largely due to a greater proportion of $\mathrm{T}^{+} \mathrm{LPL}$
$(P<0.005)$. The $\mathrm{T} 4^{+} / \mathrm{T}^{+}$LPL ratio was similar in ileal and colonic specimens. The LPL were located diffusely throughout the lamina propria in both ileal and colonic control tissues. There was no tendency for a T-cell subset to be localized to a specific area such as at the base of crypts. $\mathrm{T} 11^{+}$cells were diffusely present or were present in the periphery (mantle zone) of lymphoid aggregates. Occasional $\mathrm{T} 11^{+}$lymphocytes were present in germinal centers. $\mathrm{T}^{+}$lymphocytes were sparsely present in the periphery of lymphoid follicles and were not noted in germinal centers. $T$ helper lymphocytes were present in large numbers in the periphery of follicles as well as being present in small numbers within germinal centers. Few, if any, B1-stained lymphocytes were detected among LPL except when adjacent to areas of lymphoid aggregates. Numerous B lymphocytes were diffusely present in germinal 

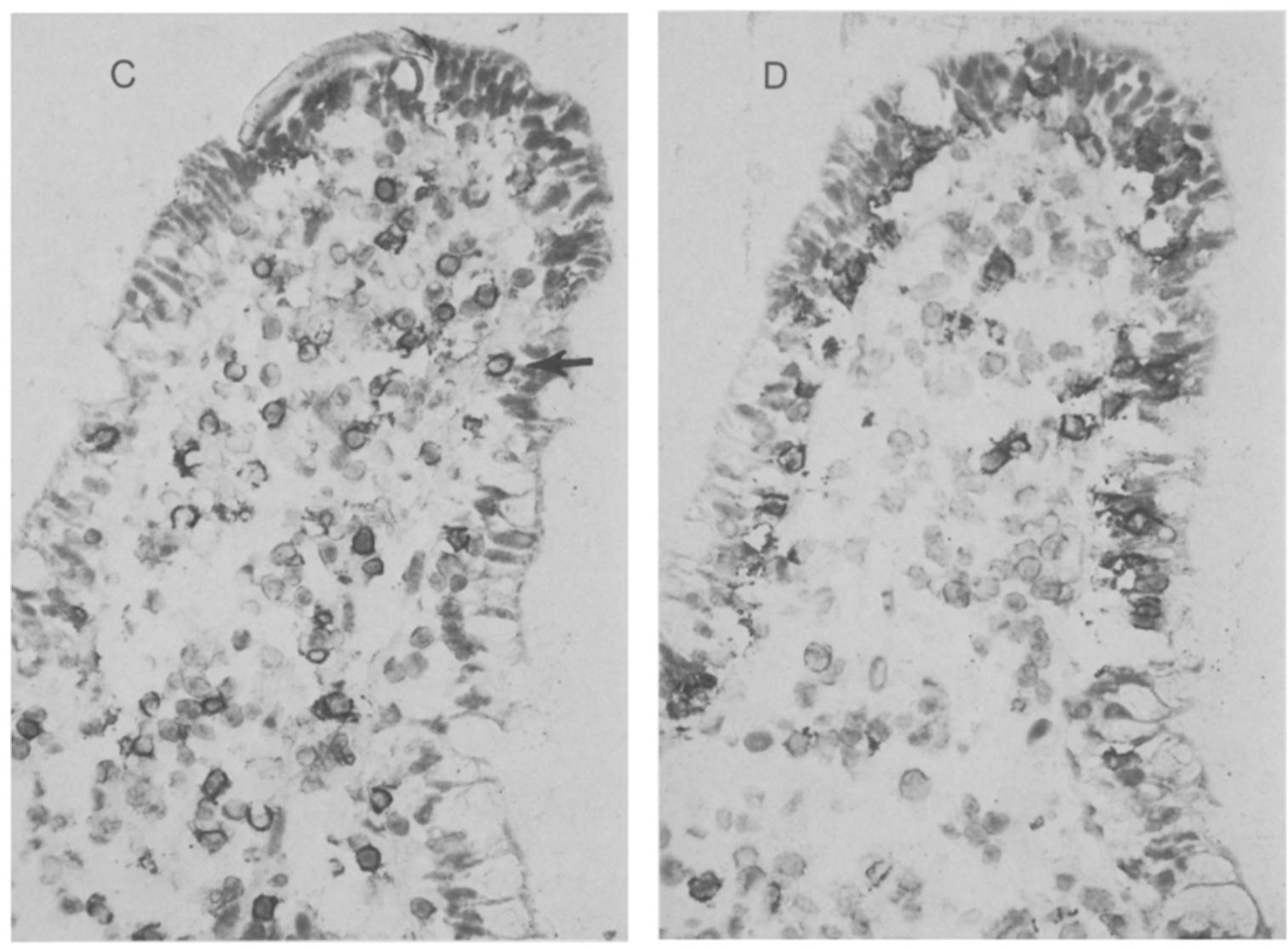

Fig 1. Continued.

centers of lymphoid aggregates and follicles. Leu 7-stained LPL were quite sparse (Table 2). Leu $7^{+}$-stained cells were occasionally noted in lymphoid aggregates, being located predominantly in the center of follicles. Surface membrane staining with anti-human HLA-DR antibody (I2) was de- tected among lamina propria mononuclear cells, dendritic appearing cells, fibroblasts, and vascular and lymphatic endothelia (Figure 2A). Mononuclear cells with the morphology of macrophages showed intense surface staining, even when using minute concentrations of antibody. Further, there ap-

Table 1. Lymphocyte Distribution in Control Ileal and Colonic Specimens*

\begin{tabular}{|c|c|c|c|c|}
\hline & $T 11$ & $T 8$ & $T 4$ & $T 4 / T 8$ \\
\hline \multicolumn{5}{|c|}{ Intraepithelial lymphocytes (IEL) } \\
\hline Ileum (7) & $\begin{array}{c}13.0 \pm 8.2 \\
\dagger\end{array}$ & $13.1 \pm 6.9$ & $\begin{array}{c}2.0 \pm 2.1 \\
\ddagger\end{array}$ & $0.13 \pm 0.1$ \\
\hline Colon $(10)$ & $5.1 \pm 3.6$ & $4.8 \pm 2.3$ & $0.69 \pm 1.1$ & $0.20 \pm 0.4$ \\
\hline \multicolumn{5}{|c|}{ Lamina propria lymphocytes (LPL) } \\
\hline Ileum $(7)$ & 33.6 \pm 5.5 & $13.0 \pm 3.5$ & $\begin{array}{c}24.8 \pm 3.7 \\
\dagger\end{array}$ & $2.0 \pm 0.6$ \\
\hline Colon $(10)$ & $27.7 \pm 6.3$ & $10.8 \pm 4.1$ & $19.0 \pm 5.9$ & $1.9 \pm 0.6$ \\
\hline
\end{tabular}

*IEL are expressed as number stained with $\mathrm{T} 11, \mathrm{~T} 8$, and $\mathrm{T} 4$ monoclonal antibody per 100 epithelial cells, and LPL as number stained per 100 mononuclear cells. T4/T8 expressed as the mean of the ratios of individual counts for each specimen. Numbers expressed as mean \pm SD. Number of patients in parentheses.

$\dagger P<0.005$.

$\ddagger P<0.05$. 

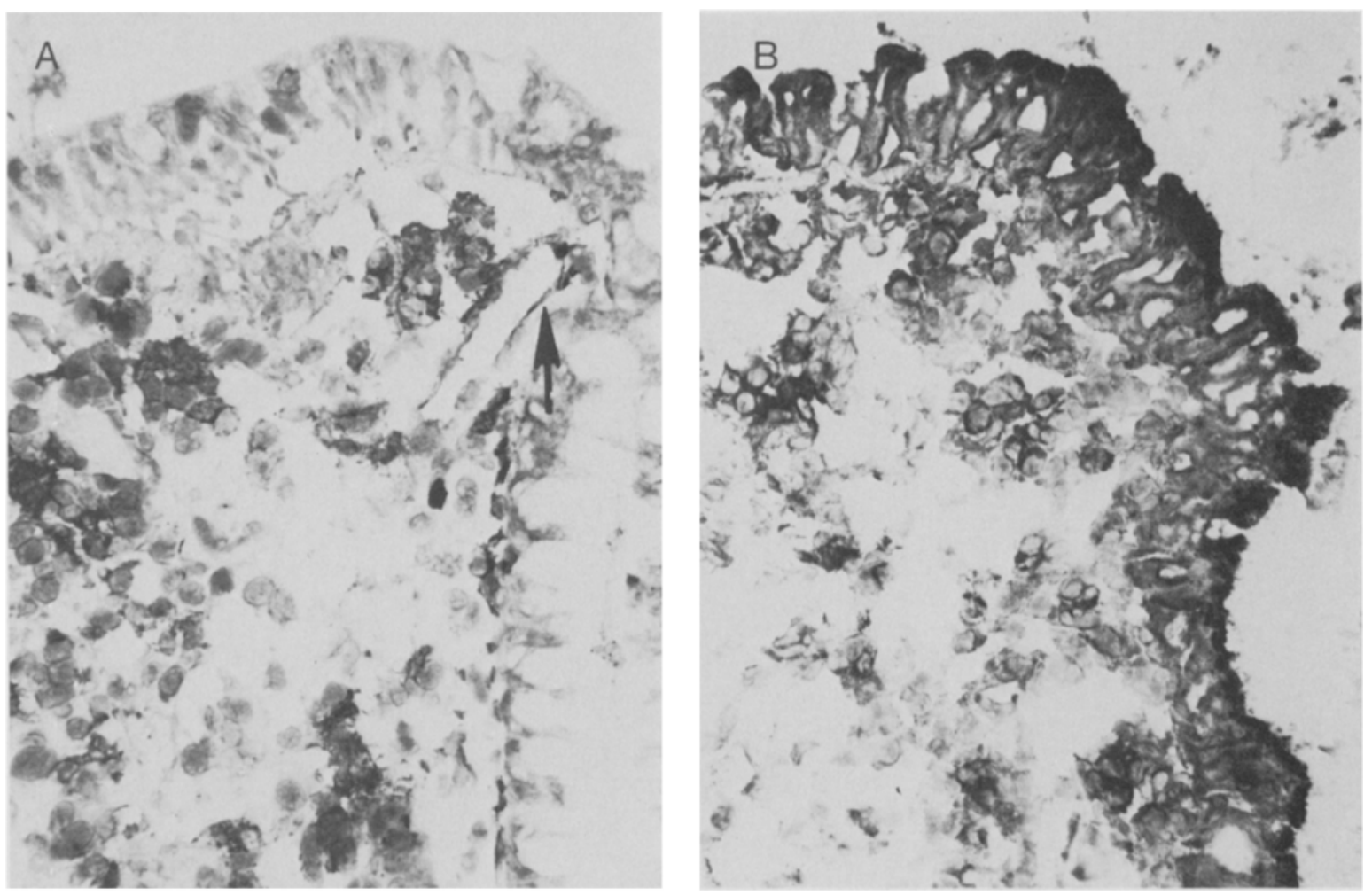

Fig 2. (A) Epithelium of normal colonic mucosa stained for HLA-DR antigen. There is no epithelial staining. Note intense peripheral staining of large mononuclear cells in the lamina propria. There is also modest staining of capillary endothelium (arrow). 500×. (B) Epithelium of diseased colon stained for HLA-DR antigen. Note strong expression of HLA-DR over apex of epithelial cells. $500 \times$.

peared to be considerable diffusion of the antigen, especially in the presence of numerous macrophages. Only when the antibody was diluted to 1:5160 $(0.18 \mu \mathrm{g} / \mathrm{ml})$ and occasionally $1: 10,320$ were

Table 2. Distribution of LPL Stained with Monoclonal ANTiBody LeU $7 *$

\begin{tabular}{lcccc}
\hline \multicolumn{1}{c}{ Tissue } & Patients & $\begin{array}{c}\text { No. } \\
\text { positive }\end{array}$ & $\begin{array}{c}\text { Leu }^{+} \\
\text {LPL/HPF }\end{array}$ \\
\hline Control ileum & 7 & 3 & $15 / 287(5.2)$ \\
Crohn's disease (ileum) & 8 & 7 & $35 / 291(12.0)$ \\
Normal margin & 8 & 6 & $62 / 500(12.4)$ \\
Control colon & 10 & 7 & $22 / 611(3.6)$ \\
$\quad$ Ulcerative colitis & 8 & 7 & $49 / 414(11.8)$ \\
$\quad$ Diseased & 2 & 2 & $8 / 102(7.8)$ \\
$\quad$ Normal margin & 3 & 3 & $22 / 85(25.9)$ \\
$\quad$ Crohn's disease (colon) & Diseased & 2 & 1 & $5 / 47 \quad(10.6)$ \\
$\quad$ Normal margin & 2 & &
\end{tabular}

*The first column represents the number of patients in whom specimens were stained with Leu 7 antibody, and the second column lists number of patients who had positively stained specimens.

+ Number of Leu $7^{+}$LPL and number of high power fields (HPF) counted. Number in parentheses is number of Leu $7^{+}$per $100 \mathrm{HPF}$. we able to adequately localize the surface staining by I 2 to macrophages. Double staining with antiT11 monoclonal antibody with fluorescein and antihuman HLA-DR antibody with avidin-HRP showed that $2.0 \%$ of $\mathrm{T} 11^{+}$LPL expressed 12 surface antigen (five colonic specimens, 1104 LPL counted; four ileal specimens, 570 LPL counted). HLA-DR staining was noted throughout lymphoid follicles, including germinal centers when present.

IEL in IBD. Virtually all IEL were $\mathrm{T} 11^{+}$cells. The total number of IEL $\left(\mathrm{T} 11^{+}\right)$increased slightly but not significantly in ulcerative colitis and in Crohn's colitis (Table 3). In contrast, the number of $\mathrm{T}_{11}{ }^{+}$IEL decreased in diseased ileum $(P<0.05$ vs control) (Table 4) and $\mathrm{T}^{+}$IEL decreased to one third of the control value in diseased ileal mucosa $(P$ $<0.005$ ). IEL $\mathrm{T}^{+} / \mathrm{T}^{+}$ratios were similar in control and colonic disease specimens, while there was an increased ratio in diseased ileum $(P<0.05)$ (Tables 3 and 4). There was a significant increase in $\mathrm{T}^{+} \mathrm{IEL}$ in grossly noninvolved areas of UC colon when compared to control colon $(P<0.05)$, but not when compared to UC-involved colon (Table 3 ). 


\section{INTESTINAL LYMPHOCYTES IN IBD}

Table 3. Lymphocyte Distribution in Ulcerative Colitis and Crohn's Colitis*

\begin{tabular}{|c|c|c|c|c|}
\hline & $T 11$ & $T 8$ & $T 4$ & $T 4 / T 8$ \\
\hline \multicolumn{5}{|c|}{ Intraepithelial lymphocytes (IEL) } \\
\hline \multicolumn{5}{|l|}{ Ulcerative colitis } \\
\hline Diseased (11) & $6.4 \pm 4.9$ & $5.0 \pm 2.8$ & $1.60 \pm 1.5$ & $0.33 \pm 0.3$ \\
\hline Normal margin (4) & $7.5 \pm 1.9$ & $6.8 \pm 1.3 \dagger$ & $0.80 \pm 0.3$ & $0.12 \pm 0.04$ \\
\hline \multicolumn{5}{|c|}{ Crohn's disease of colon } \\
\hline Diseased (3) & $6.7 \pm 1.4$ & $4.7 \pm 1.0$ & $0.78 \pm 0.7$ & $0.16 \pm 0.2$ \\
\hline Normal margin (3) & $5.5 \pm 1.4$ & $5.1 \pm 2.4$ & $0.66 \pm 0.4$ & $0.22 \pm 0.3$ \\
\hline \multicolumn{5}{|c|}{ Lamina propria lymphocytes (LPL) } \\
\hline \multicolumn{5}{|l|}{ Ulcerative colitis } \\
\hline Diseased (11) & $24.6 \pm 6.5$ & $9.4 \pm 3.9$ & $20.5 \pm 7.1$ & $2.3 \pm 0.7$ \\
\hline Normal margin (4) & $25.5 \pm 3.2$ & $12.1 \pm 1.5$ & $25.5 \pm 1.8 \ddagger$ & $2.1 \pm 1.3$ \\
\hline \multicolumn{5}{|l|}{ Crohn's colitis } \\
\hline Diseased (3) & $21.0 \pm 5.8$ & $8.1 \pm 1.9$ & $17.9 \pm 5.2$ & $2.3 \pm 0.9$ \\
\hline Normal margin (3) & $24.0 \pm 10.4$ & $11.6 \pm 4.3$ & $23.4 \pm 9.3$ & $2.2=1.1$ \\
\hline
\end{tabular}

*IEL are expressed as number stained with T11, T8, and T4 monoclonal antibody per 100 epithelial cells, and LPL as number stained per 100 mononuclear cells. T4/T8 expressed as the mean of the ratios of individual counts for each specimen. Results expressed as mean \pm SD. Number of patients in parentheses.

$\dagger P<0.05$ when compared to control colon.

$\ddagger P<0.01$.

$\mathrm{B} 1^{+}$lymphocytes were rarely detected in diseased epithelium, 1.5 per 100 high power fields in Crohn's ileum (217 HPF counted) and 1 per 100 high power fields in UC (291 HPF counted). Less than 1 per 100 HPF Leu $7^{+}$lymphocytes were observed in specimens of one of 11 patients with Crohn's disease of colon and ileum (400 HPF counted) and one of eight patients with ulcerative colitis (414 HPF counted). I2 staining in IBD was remarkable in that the epithelium of all samples of grossly involved colonic mucosa obtained from patients with UC and Crohn's colitis was positive while normal colonic epithelium did not express I2 (Figure 2A, B). Two of 10 patients with Crohn's ileitis and colitis had one and two IEL stained with anti-12, respectively, in 271 HPF counted. None of the UC patients had $\mathrm{I}^{+}$IEL in $229 \mathrm{HPF}$.

LPL in IBD. T cells in ulcerative colitis were not significantly different from control specimens, ex- cept that the number of $\mathrm{T}^{+} \mathrm{LPL}$ were significantly increased in grossly noninvolved margins in ulcerative colitis $(P<0.01)$ (Table 3$)$. $\mathrm{T}^{+} / \mathrm{T} 8^{+}$ratios were similar in diseased and control tissues. $\mathrm{T}$ lymphocyte subsets in Crohn's ileitis specimens were similar to the control ileal samples except for a significant decrease in number of $\mathrm{T} 11^{+}$lymphocytes per 100 mononuclear cells in involved $(P<$ $0.05)$ and noninvolved areas $(P<0.005)$ when compared to control (Table 4). There were no significant changes in $\mathrm{T}^{+} / \mathrm{T}^{+}$ratios. No apparent differences could be detected in the $T$ lymphocyte subset distribution in lymphoid aggregates found in ulcerative colitis and Crohn's colitis specimens when compared to control. Four of eight patients with Crohn's ileitis had a total of $18 \mathrm{~B}^{+}$lymphocytes in $217 \mathrm{HPF}$ counted and four of 11 patients with ulcerative colitis had a total of $11 \mathrm{~B}^{+}$lympho-

Table 4. Lymphocyte Populations in Crohn's Disease of Ileum

\begin{tabular}{lcccc}
\hline \multicolumn{1}{c}{$T 11$} & \multicolumn{1}{c}{$T 8$} & $T 4$ & $T 4 / T 8$ \\
\hline Intraepithelial lymphocytes (IEL) & $6.6 \pm 4.4 \dagger$ & $4.31 \pm 2.3 \dagger$ & $1.1 \pm 0.7$ & $0.37 \pm 0.5 \dagger$ \\
Diseased (8) & $7.1 \pm 3.2 \dagger$ & $8.0 \pm 6.1 \dagger$ & $1.5 \pm 1.0$ & $0.22 \pm 1.0 \dagger$ \\
Normal margin (8) & & & \\
Lamina propria lymphocytes (LPL) & $27.5 \pm 7.0 \dagger$ & $11.3 \pm 4.6$ & $21.5 \pm 5.0$ & $2.2 \pm 0.9$ \\
$\quad$ Diseased (8) & $25.0 \pm 7.4 \dagger$ & $13.6 \pm 4.9$ & $24.3 \pm 5.7$ & $2.0 \pm 0.7$ \\
\hline
\end{tabular}

*IEL are expressed as number stained with T11, T8, and T4 monoclonal antibody per 100 epithelial cells, and LPL as number stained per 100 mononuclear cells. T4/T8 expressed as the mean of the ratios of individual counts for each specimen. Results expressed as mean \pm SD. Number of patients in parentheses.

$\dagger P<0.005$ when compared to control.

$\ddagger P<0.05$. 

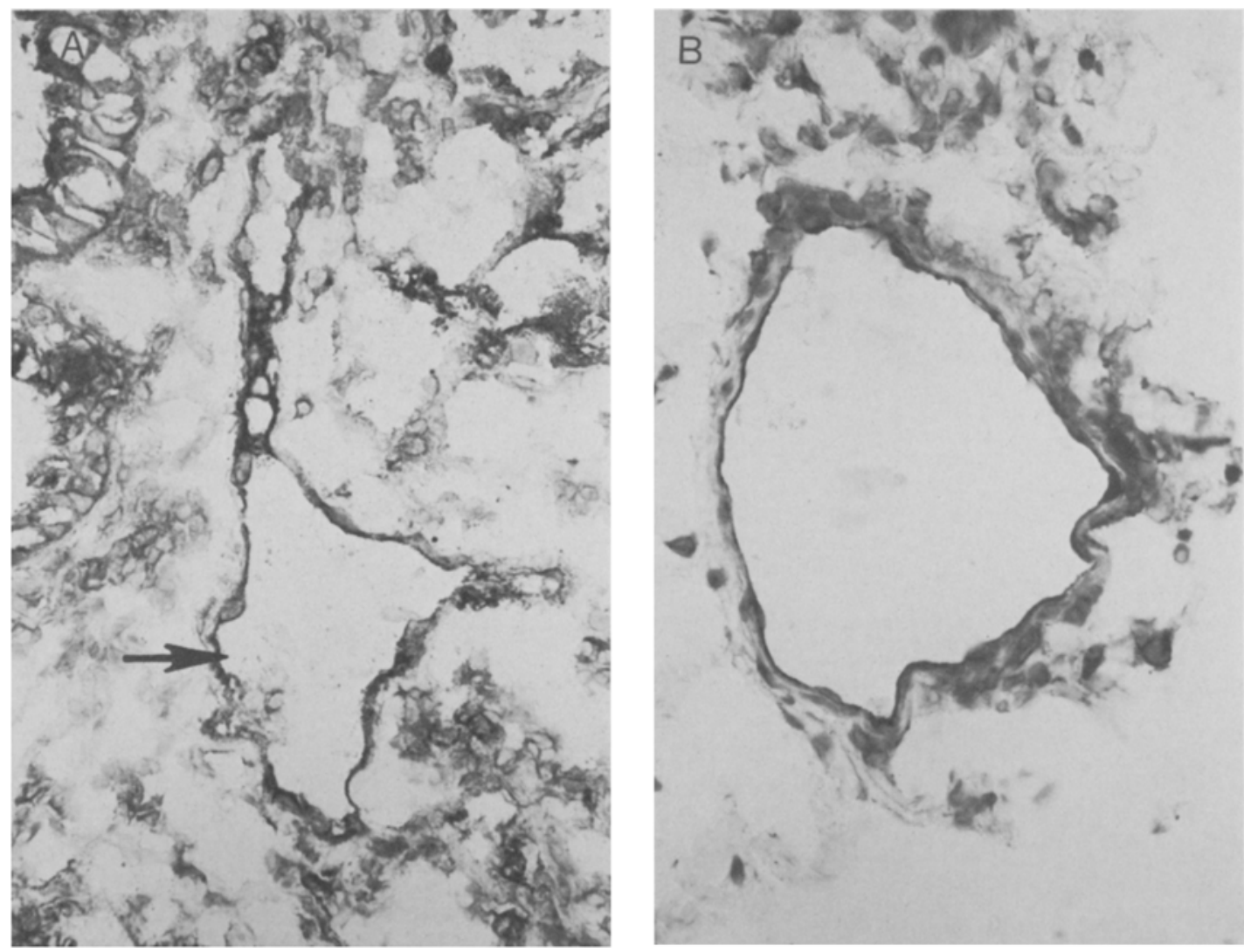

Fig 3. (A) Mucosa in Crohn's ileitis specimen stained for HLA-DR antigen demonstrating staining of epithelium, large mononuclear cells in the lamina propria, and of the endothelium of a lacteal (arrow). 500X. (B) Submucosa in Crohn's ileitis specimen stained for HLA-DR antigen demonstrating strong staining of capillary endothelium. 500 $\times$.

cytes in 291 HPF counted. Two patients with Crohn's ileitis had lymphoid aggregates with B cells located predominantly in germinal centers; four patients with ulcerative colitis had numerous B cells in the center of lymphoid aggregates. Seven of eight patients with Crohn's ileitis, seven of eight patients with ulcerative colitis, and all three patients with Crohn's colitis had presence of small numbers of Leu $7^{+}$cells (Table 2). Leu $7^{+}$lymphocytes were detected in small numbers within lymphoid aggregates in ulcerative colitis specimens but were not present within lymphoid aggregates of the three Crohn's ileitis specimens. 12 antibody stained macrophages, vascular and lymphatic endothelia (Figure $3 \mathrm{~A}, \mathrm{~B})$, and fibroblasts. Diffusion of antigen around macrophages was again prominent at lower concentrations of antibody. Double staining with T11 antibody and $\mathrm{I} 2$ antibody detected $0.8 \% \pm 1.3$ $\mathrm{I}^{+} / \mathrm{T} 11^{+}$LPL in ulcerative colitis (seven specimens, 1026 counts) and $1.3 \% \pm 1.1 \mathrm{I}^{+} / \mathrm{T} 11^{+} \mathrm{LPL}$ in Crohn's ileitis tissues (five specimens, 1269 counts). All specimens containing lymphoid follicles showed diffuse anti-HLA-DR staining within the follicle, ie, most cells appeared to be stained.

We did not compare data in steroid-treated patients versus non-steroid-treated patients because the sample size of non-steroid-treated patients was not large enough to permit valid conclusions.

\section{DISCUSSION}

We have characterized IEL and LPL distribution in control colon and ileum and in ulcerative colitis and in Crohn's disease, using monoclonal antibodies to $\mathrm{T}$ and B lymphocytes, natural killer cells, and to HLA-DR antigen. We report analysis of lymphocyte distribution in ileal Crohn's disease for the first time and provide extensive quantitative data concerning lymphocyte distribution in colonic Crohn's disease and in ulcerative colitis. IEL are T lymphocytes with the predominant subset being the $T$ suppressor $\left(\mathrm{T}^{+}\right)$type in both ileal and in colonic 
mucosa. Control ileal tissues had significantly greater numbers of $\mathrm{T}_{1} 1^{+}, \mathrm{T} 8^{+}$, and $\mathrm{T} 4^{+}$IEL than did control colonic tissues while the $\mathrm{T} 4$ to $\mathrm{T} 8$ ratios were similar in both tissues. Our data in control ileal specimens is similar to that of Cerf-Bensussan et al, who reported $12 \pm 5.0 \mathrm{~T}$ lymphocytes $/ 100$ epithelial cells, and $11 \pm 6.0 \mathrm{~T}$ suppressor $\left(\mathrm{T}^{+}\right)$lymphocytes/100 epithelial cells in "three specimens of normal small intestine" (3). However, Cerf-Bensussan et al found three times as many $\mathrm{T}$ helper $\left(\mathrm{T}^{+}\right)$ IEL/100 epithelial cells than we found (3). This difference may be due to the differences in technique, differences in specificity of the anti-T4 monoclonal antibody used, or to differences in tissue (ileum vs probable jejunum). We show quantitatively that the predominance of $\mathrm{T}$ suppressor $\left(\mathrm{T}^{+}\right)$ IEL lymphocytes is maintained in UC and CD (4), and demonstrate this in both grossly involved and grossly noninvolved areas of the ileum and colon. There was a significant increase of $\mathrm{T}^{+}$IEL in grossly normal margins of UC specimens. There was a significant decrease in the number of IEL in diseased tissues in ileal $C D$.

IEL are clearly a heterogenous population of cells with heterogenous functions. We have focused on epithelial lymphocytes in this study, but other cells, including PMN leukocytes, eosinophils, mast cells, and macrophages, may be found within the epithelium $(2,8)$. IEL are increased in numbers in several disease states including celiac sprue, tropical sprue, and dermatitis herpetiformis (6-8). In celiac sprue, the T4 to T8 ratio of IEL is unchanged when compared to normal, but the proportion of $\mathrm{T}^{+}$IEL expressing the pan $\mathrm{T}$ cell marker, Leu 1, is significantly increased when compared to IEL of normal intestine (56\% vs $32 \%$ ) (6). IEL in celiac sprue may reflect increased traffic into the epithelium, although the function of human IEL is not known (6). The epithelium is ideally suited to the function of suppressor $\left(\mathrm{T}^{+}\right)$cells because of its strong expression of class I MHC antigens. The small population of helper $\left(\mathrm{T}^{+}\right)$cells within the epithelium may add further control over the functions of $\mathrm{T} 8^{+}$IEL (6).

We have shown some changes in IEL numbers and distribution in IBD, but these are rather minor in numerical terms, and there is no change in $\mathrm{T} 4$ to T8 ratio or increase in number of IEL in colonic IBD. IEL do show an increase in the T4 to T8 ratio and are decreased in number in ileal CD. Thus there is no increase (and even a decrease in Crohn's ileitis) in traffic of IEL in IBD. Epithelial expression of HLA-DR antigen may well play a role in antigen presentation to IEL (see later discussion), although this is speculative at best. The role of PMN leukocytes in injury to epithelial cells, particularly in UC, is a topic beyond the scope of this study.

Finally, it should be noted that human IEL, in contrast to rodent IEL, do not contain large granules $(1-3,8)$. Occasional small granules are present within human IEL, but these are probably lysosomes (1-3). Rodent IEL may be mast cell derived, while there is no evidence that human IEL are mast cell in origin (19).

There are two methods of quantitation of IEL. One is to count the number of IEL per unit area of mucosa and the other is to count the number of IEL per 100 epithelial cells (20). For example, in celiac sprue there is an increase in numbers of IEL/100 epithelial cells while there is a decrease in numbers of IEL per unit area (millimeters of muscularis mucosae) of gut (20). The epithelial region is morphologically and functionally different from the lamina propria region $(1,3,5-7,20)$. We suggest that the IEL immune role is directed towards the epithelial cell $(1,2)$. Thus, we chose to quantitate the number of IEL/100 epithelial cells. We emphasize, however, that the method of quantitation of IEL must be considered to be arbitrary and the "correct" method of quantitation has not been established.

We confirm that few B lymphocytes were found in the IEL population $(3,4,7)$ and those few cells could have represented artifactual staining. The paucity of natural killer cells (Leu $7^{+}$) among IEL in control tissues as well as in diseased areas confirms earlier studies $(3,6)$.

The expression of HLA-DR antigen on macrophages and lymphocytes is one indication of immune activation (21). Our data indicate that the IEL is not an activated cell (4-6), at least on the basis of I2 expression. Normal intestinal epithelium and ileal CD epithelium express 12 , while control colonic epithelium did not. The epithelium of all colonic IBD specimens expressed I2. The induction of epithelial cell expression of HLA-DR-like antigen in UC has been used to suggest an autoimmune mechanism for colonic IBD (22), but there is no direct data bearing on this supposition. However, it has been shown that both induction of graft-vs-host disease and naturally occurring immunological stimuli can also induce the expression of Ia antigens (HLA-DR-like) in rat intestinal epithelium (23).

In regard to LPL, there were more $\mathrm{T}$ lymphocytes $\left(\mathrm{T} 11^{+}\right)$per 100 mononuclear cells in control 
ileum than in control colon, while the $\mathrm{T} 4^{+} / \mathrm{T}^{+}$ ratios were similar in both tissues. The ratio of $\mathrm{T4}^{+} / \mathrm{T}^{+} \mathrm{LPL}$ in grossly diseased tissues in ulcerative colitis and in Crohn's colitis and ileitis was similar to that of controls. Interestingly, there was a significant increase in the proportion of $T$ helper cells in normal margins of ulcerative colitis specimens. However, there was a sufficient increase in $T$ suppressor cells so that the T4/T8 ratio was not significantly changed. Our data show that there is a generalized inflammatory response in IBD which includes $T$ cells and that there is no change in ratio of helper $\left(\mathrm{T}^{+}\right)$cells to suppressor $\left(\mathrm{T}^{+}\right)$cells. In Crohn's ileitis there was a decrease in the proportion of $\mathrm{T} 1^{+}$cells $/ 100 \mathrm{MNC}$ but no change in the ratio of $\mathrm{T}^{+} / \mathrm{T}^{+}$cells. This decrease in the proportion of $\mathrm{T} 11^{+}$cells may be secondary to an increased infiltration by other MNC such as plasma cells and macrophages. Plasma cells were included in our counts of MNC but were not counted separately. An increase in lamina propria plasma cells in IBD is well documented (24).

Lymphocytes staining with anti-B1 monoclonal antibody were so rare among diffuse lymphoid tissues in control and disease specimens as to be regarded as artifactual. B cells were prominent, as expected, within germinal centers of lymphoid aggregates. Plasma cells lose the antigenic marker defined by anti-B1 when they differentiate from B cells, and presumably $B$ cells that home to the mucosa lose the B1 marker prior to localization in the lamina propria. We did note an increase in $\mathrm{B}$ cells in Crohn's colitis, but these were generally located adjacent to lymphoid aggregates, where $\mathrm{B}^{+}$cells are normally present.

Natural killer (Leu $7^{+}$) lymphocytes were rarely detected in control ileal specimens. This supports other immunohistological and in vitro data indicating that there are few natural killer cells among LPL $(4,6,25)$. We did find more Leu $7^{+}$cells/HPF in specimens from patients with Crohn's ileitis, Crohn's colitis, and in ulcerative colitis. This finding may be part of a generalized inflammatory response and does not necessarily indicate a primary role for NK cells in IBD. Recently, Leu 11a monoclonal antibody has been shown to label all cells with natural killer (NK) activity, while Leu 7 labels only $80 \%$ of NK activity. We have utilized fluorosceinated Leu 11a (data not shown) in selected tissues (those showing occasional Leu $7^{+}$ cells) and confirm that there are comparable numbers of labeled cells using both techniques. Targan et al (26) have shown, in contrast to earlier conflicting reports, that natural killer cell activity is present in the colonic mucosa and that it constitutes only about $1.5 \%$ of isolated IEL and LPL combined. Our data are consistent with the findings of Targan et al of a paucity of natural killer cells in the colonic mucosa.

Few lamina propria $\mathrm{T}$ cells expressed I2, either in control or in IBD specimens. Similar findings were reported in control ileum by Cerf-Bensussan et al and in IBD by Selby et al $(3,4)$. I2 (HLA-DR) expression by macrophages, by capillary and lymphatic endothelia, and by cells similar morphologically to fibroblasts was present. The expression by macrophages was intense. I2 expression by monocytes and macrophages, capillary endothelia, intestinal epithelium, and fibroblasts is documented (21, 22, 27-29). We describe I2 localization to lymphatic endothelia in the intestine for the first time. HLADR-like (class II MHC antigen) expression is required in the initiation of the T-helper response to many antigens, including bacterial antigens (22). The strong expression of HLA-DR may play a role in the immune response (hyperresponse?) of IBD.

\section{ACKNOWLEDGMENTS}

We are grateful to Dr. Henry D. Appelman, Chief, Surgical Pathology at the University of Michigan, who greatly assisted us in obtaining surgical tissues and reviewing the pathological findings. We thank Thomas Morrow, $\mathrm{PhD}$, for his assistance in analyzing our data statistically. The authors wish to thank Ms. Ann Marie Steffen for her valuable and patient assistance in preparing this manuscript.

\section{REFERENCES}

1. Greenwood JH, Austin LL, Dobbins WO III: In vitro characterization of human intestinal intraepithelial lymphocytes. Gastroenterology 85:1023-1035, 1983

2. Austin LL, Dobbins WO III: Intraepithelial leukocytes of the intestinal mucosa in normal man and in Whipple's disease. A light- and electron-microscopic study. Dig Dis Sci 27:311-319, 1982

3. Cerf-Bensussan N, Schneeberger EE, Bhan AK: Immunohistologic and immunoelectron microscopic characterization of the mucosal lymphocytes of human small intestine by the use of monoclonal antibodies. J Immunol 130:2615-2622, 1983

4. Selby WS, Janossy G, Bofill M, Jewell DP: Intestinal lymphocyte subpopulations in inflammatory bowel disease: An analysis by immunohistological and cell isolation techniques. Gut 25:32-40, 1984

5. Selby WS, Janossy G, Goldstein G, Jewell DP: 'T lymphocyte subsets in human intestinal mucosa: The distribution 
and relationship to $\mathrm{MHC}$-derived antigens. Clin Exp Immunol 44:453-458, 1981

6. Selby WS, Janossy G, Bofill M, Jewell DP: Lymphocyte subpopulations in the human small intestine. The findings in normal mucosa and in the mucosa of patients with adult coeliac disease. Clin Exp Immunol 52:219-228, 1983

7. Selby WS, Janossy G, Jewell DP: Immunohistological characterization of intraepithelial lymphocytes of the human gastrointestinal tract. Gut 22:169-176, 1981

8. Ferguson A: Progress report: Intraepithelial lymphocytes of the small intestine. Gut 18:921-937, 1977

9. Warnke R, Levy D: Detection of $\mathrm{T}$ and $\mathrm{B}$ cell antigens with hybridoma monoclonal antibodies. J Histochem Cytochem 28:771-776, 1979

10. Colucci G, Colombo M, DelNinno E, Paronetto F: In situ characterization by monoclonal antibodies of the mononuclear cell infiltrate in chronic active hepatitis. Gastroenterology 85:1138-1145, 1983

11. Nakane PK: Localization of hormones with the peroxidaselabeled antibody method. Methods Enzymol 37 (part B): 133-144, 1975

12. VanVoorhis WC, Kaplan SBG, Sarno EN, Horwitz MA, Steinman RM, Levis WR, Nogueira N, Hair LS, Gattass $\mathrm{CR}$, Arrick BA, Cohn ZA: The cutaneous infiltrates of leprosy. Cellular characteristics and the predominant $\mathrm{T}$-cell phenotype. N Engl J Med 307:1593-1597, 1982

13. Hsu S-M, Raine L: Protein A, avidin, and biotin in immunohistochemistry. J Histochem Cytochem 29:1349-1353, 1981

14. Hsu S-M, Raine L, Fanger H: Use of avidin-biotin-peroxidase complex $(\mathrm{ABC})$ in immunoperoxidase techniques: $A$ comparison between $\mathrm{ABC}$ and unlabeled antibody (PAP) procedures. J Histochem Cytochem 29:577-580, 1981

15. Isobe $Y$, Chen S-T, Nakane PK, Brown WR: Studies on translocation of immunoglobulins across intestinal epithelium. I. Improvements in the peroxidase-labeled antibody method for application to study of human intestinal mucosa. Acta Histochem Cytochem 10:161-171, 1977

16. Straus W: Peroxidase procedures. Technical problems encountered during their application. J Histochem Cytochem 27:1349--1351, 1979

17. Brill AS, Weinryb I: Reactions of horseradish peroxidase with azide. Evidence for a methionine residue at the active site. Biochemistry 6:3528-3535, 1967
18. Lechago J, Sun NCJ, Weinstein WM: Simultaneous visualization of two antigens in the same tissue section by combining immunoperoxidase with immunofluorescence techniques. J Histochem Cytochem 27:1221-1225, 1979

19. Cerf-Bensussan N, Guy-Grand D, Griscelli C: Intraepithelial lymphocytes of human gut: Isolation, characterization, and study of natural killer activity. Gut 26:81-88, 1985

20. Corazza GR, Frazzoni M, Gasbarrini G: Jejunal intraepithelial lymphocytes in coeliac disease: Are they increased or decreased? Gut 25:158-162, 1984

21. Unanue ER, Beller DI, Lu CY, Allen PM: Opinion: Antigen presentation: Comments on its regulation and presentation. $J$ Immunol 132:1-5, 1984

22. Bottazo GF, Pujol-Borrell R, Hanafusa T, Feldman M: Role of aberrant HLA-DR expression and antigen presentation in induction of endocrine autoimmunity. Lancet 2:115-118, 1983

23. Barclay AN, Mason DW: Induction of Ia antigen in rat epidermal cells and gut epithelium by immunological stimuli. J Exp Med 156:1665-1676, 1982

24. Keren DF, Appelman HD, Dobbins WO III, Wells JJ, Whisenant B, Foley J, Dieterle R, Geisinger K: Correlation of histopathologic evidence of disease activity with the immunoglobulin containing cells in the colon of patients with inflammatory bowel disease. Hum Pathol 15:757 763, 1984

25. Fiocchi C, Youngman KR, Farmer RG: Immunoregulatory function of human intestinal mucosa lymphoid cells: Evidence for enhanced suppressor cell activity in inflammatory bowel disease. Gut 24:692-701, 1983

26. Targan S, Britvan L, Kendal R, Vimadalal S, Soll A: Isolation of spontaneous and interferon-inducible natural killer like cells from human colonic mucosa: Lysis of lymphoid and autologous epithelial target cells. Clin Exp Immunol 54:14-22, 1983

27. Scott H, Solheim BG, Brandtzaeg P, Thorsby E: HLA-DRlike antigens in the epithelium of the human small intestine. Scand J Immunol 12:77-82, 1980

28. Shiozawa S, Shiozawa K, Fujita T: Presence of HLA-DR antigen on synovial type $A$ and $B$ cells: An immunoelectron microscopic study in rheumatoid arthritis, osteoarthritis and normal traumatic joints. Immunology 50:587-594, 1983

29. Bienenstock J, Befus AD, Pearce F, Denburg J, Goodacre R: Mast cell heterogeneity: Derivation and function, with emphasis on the intestine. J Allergy Clin Immunol 70:407-412, 1982 